\title{
Imperforate Anus
}

National Cancer Institute

\section{Source}

National Cancer Institute. Imperforate Anus. NCI Thesaurus. Code C84784.

A cong enital birth defect characterized by the absence of a normal anal opening. It may be associated with other congenital abnormalities. 